\title{
Growth suppression of four cancer cells by hyperbaric nitrous oxide and methotrexate
}

\author{
Cheol Hee Jung, Ji Yeon Sim*, and Wonsik Ahn
}

Department of Anesthesiology and Pain Medicine, Seoul National University Hospital, *College of Medicine, University of Ulsan, Seoul, Korea

Background: Nitrous oxide concentration is easily controlled by respiratory ventilation. It suppresses bone marrow via the inhibition of thymidylate synthesis. The aim of this work was to determine the optimal pressure and exposure duration of nitrous oxide, as well as methotrexate concentration that maximizes the suppression of 4 cancer cells: CCRF-CEM, K562, A549 and MDA-MB-231. Methods: Each cancer cell was cultured in a hyperbaric chamber at 1, 2 and 3 atmosphere of $74 \%$ nitrous oxide for 24, 48, and 72 hours at 0, 0.3, 0.7, 1, 2, 5 and $10 \mu \mathrm{M}$ methotrexate (MTX), respectively. The results were expressed in the ratio of the number of cancer cells cultured under specific conditions (S cells) to that under normal conditions (N cells). Results: The S/N ratio of CCRF-CEM cells was $87.4 \%$ in 24 -hour culture, $95.0 \%$ in 48 -hour culture and $115.9 \%$ in 72 -hour culture $(P<0.05)$. The $S / N$ ratio of $K 562$ cells was $103.6 \%$ at $1 \mathrm{~atm}, 102.4 \%$ at $2 \mathrm{~atm}$ and $115.6 \%$ at $3 \mathrm{~atm}(\mathrm{P}<0.05)$. The $\mathrm{S} / \mathrm{N}$ ratio of A549 cells was 94.3\% at $1 \mathrm{~atm}, 94.1 \%$ at $2 \mathrm{~atm}, 99.3 \%$ at $3 \mathrm{~atm}, 96.2 \%$ in 24-hour culture, 99.2\% in 48-hour culture and 99.3\% in 72-hour culture ( $P>0.05)$. However, the $S / N$ ratio of MDA-MB 231 cells was $66.9 \%$ in 24-hour culture, $83.1 \%$ in 48 hour culture and $87.8 \%$ in 72 -hour culture $(P<0.05)$. Conclusions: Only the growth of the MDA-MB-231 cells was significantly reduced after a longer exposure time to nitrous oxide, but those of the other cells were not. (Korean $\mathrm{J}$ Anesthesiol 2010; 58: 61 69)

\section{Key Words: Methotrexate, Nitrous oxide, Tumor growth suppression.}

\section{Introduction}

Treatment of malignant tumors, which are difficult to manage and lead to death, still remains as a main issue in modern medicine. The morphology of malignant tumors is non-specific and has different characteristics according to the occurrence site and surrounding conditions. For this reason, their treatment methods are non-specific, and thus various approaches have been attempted to date. Surgical resection, chemotherapy and radiotherapy are currently the representative treatment modalities with different treatment outcomes [1]. The main issue concerning the treatment of malignant tumors is to develop new antitumor

Received: May 19, 2009. Revised: 1st, May 29, 2009; 2nd, August 29, 2009. Accepted: September 14, 2009.

Corresponding author: Wonsik Ahn, M.D., Department of Anesthesiology and Pain Medicine, Seoul National University Hospital, 28, Yeongeon-dong, Jongno-gu, Seoul 110-744, Korea. Tel: 82-2-2072-3087, Fax: 82-2-747-5639, E-mail: aws@snu.ac.kr

(C) This is an open-access article distributed under the terms of the Creative Commons Attribution Non-Commercial License (http:// creativecommons.org/licenses/by-nc/3.0/), which permits unrestricted non-commercial use, distribution, and reproduction in any medium, provided the original work is properly cited. 
agents that have reasonable prices and excellent efficacy with controllability, among which nitrous oxide has been extensively studied.

Nitrous oxide, a widely used anesthetic, allows for rapid induction and arousal and has an analgesic effect. There have been numerous studies on the depth of anesthesia and toxicity to the body organs by this agent [2-6]. However, several side effects were reported when nitrous oxide was used in combination with inhalation anesthetics: impairment of hematopoiesis after $\geq 6$ hours of anesthesia, megaloblastic pancytopenia after $\geq 24$ hours of anesthesia and neurodegeneration and myelinopathy after long-term use [7]. It has been demonstrated that such side effects are attributed to the inhibition of DNA synthesis that results from the inactivation of methionine synthase by nitrous oxide [8, 9]. In addition, it has been suggested that hyperbaric nitrous oxide and methotrexate suppress the growth of leukemic cells [10]. Based on these results, we hypothesized that a large amount of nitrous oxide could suppress cell growth.

In this study, we used the following 4 kinds of cancer cells: adhesion cells from the hematologic malignant cell line, suspension cells from the hematologic cell line, adhesion cells from the solid cancer cell line and suspension cells from the solid cancer cell line. These cells were cultured with hyperbaric nitrous oxide to determine whether they could suppress cell growth, and they were also cultured with both hyperbaric nitrous oxide and methotrexate (MTX) to evaluate the growth rate of cancer cells at different pressures.

\section{Materials and Methods}

\section{Materials}

Among the commercially available cell lines, 2 adhesion cells (CCRF-CEM and K562) and 2 suspension cells (MAD-MB-231 and A549) were thawed (Table 1). After 1 of the 4 kinds of cells was selected using a random number table, it was cultured in RPMI medium containing penicillin-streptomycin and 10\% fetal bovine serum (Dulbecco modified eagle medium for MDA-MB-231) in an $\mathrm{CO}_{2}$ incubator at $37^{\circ} \mathrm{C}$ for 24 hours.

\section{Methods}

Culture of cancer cells: For CCRF-CEM and K562 (suspension cells), the mixture was centrifuged $1,000 \mathrm{rpm}$ at $20-25^{\circ} \mathrm{C}$ for 3 minutes. After the medium was discarded, the remaining cells were mixed with fresh medium and placed on two 96well plates at $2 \times 10^{5}$ cells/ml. For MDA-MB-231 and A549 (adhesion cells), after the medium in a T75 flask was sucked out, the flask was washed twice. After the addition of $1 \mathrm{ml}$ of trypsin-EDTA, the cells were incubated at $37^{\circ} \mathrm{C}$ for 3 minutes. The cells were detached from the wall by gentle tapping, which was confirmed using a microscope. After $10 \mathrm{ml}$ of medium were added, it was centrifuged at 1,000 rpm for 3 minutes. After the medium was discarded and replaced with a fresh one, the cells were placed on two 96-well plates at 2 $\times 10^{5}$ cells $/ \mathrm{ml}$. One plate was placed in an incubator under normal conditions containing $5 \% \mathrm{CO}_{2}$, and the other was placed in an incubator under specific conditions at different durations of time (24, 48 and 72 hours), one pressure setting (1 atm) and different concentrations of $\operatorname{MTX}(0,0.3,0.5,0.7,1,2,5$ and $10 \mu \mathrm{M})$. Under specific conditions, the cells were cultured with nitrous oxide in an atmosphere of $5 \% \mathrm{CO}_{2}-21 \% \mathrm{O}_{2}$ at 1, 2 and 3 atm for 24, 48 and 72 hours. Then, the cell wells taken out of the incubators were mixed with $100 \mu$ l of methyl thiazol tetrazolium solution and cultured at $37^{\circ} \mathrm{C}$ for 4 hours. After the medium was discarded, $100 \mu$ l of dimethyl sulphoxide were added to the cell wells by pipeting, mixed well and allowed to be left for 5 minutes. Optical density was measured at $540 \mathrm{~nm}$ using an enzyme-linked immunoassay (ELISA). The numbers of cells cultured under normal conditions ( $\mathrm{N}$ cells) and under specific conditions (S cells) were measured using an ELISA, and the ratio of $\mathrm{S}$ cells to $\mathrm{N}$ cells ( $\mathrm{S} / \mathrm{N}$ ratio) was calculated to assess the degree of growth suppression of the cancer cells. For all cell groups, the experiments were repeatedly conducted 5 times under the same conditions, and the mean values were obtained.

\section{Statistical analysis}

The data are expressed as the S/N ratio at the aforemen-

Table 1. Characteristics of Each Cancer Cell Line

\begin{tabular}{|c|c|c|c|c|}
\hline & CCRF-CEM & K562 & A549 & MDA-MB \\
\hline Tissue & T lymphoblast & Pleural effusion & Explanted lung & Breast \\
\hline \multirow[t]{2}{*}{ Species } & Human & Human & Human & Human \\
\hline & Female, 4 yr old & Female, 53-yr old & Male, 58-yr old & Female \\
\hline Growth morphology & Suspension & Suspension & Adhesion & Adhesion \\
\hline Pathology & Leukemia, Acute lymphoblastic & Leukemia, Chronic myelogenous & Lung carcinoma & Breast \\
\hline Remark & & In terminal blast crisis & & \\
\hline
\end{tabular}


tioned different conditions. In other words, the denominator represents the number of cells cultured under normal conditions, and the nominator represents the number of cells obtained after these cultured cells were placed on a 96-well plate at $2 \times 10^{5} / \mathrm{ml}$ and then cultured under specific conditions.

At a certain condition, the rate of cell growth was calculated using the following

equation:

the rate of cell growth $=\mathrm{S} / \mathrm{N} \times 100$

where

$\mathrm{S}=$ the number of cells cultured under specific conditions and

$\mathrm{N}=$ the number of cells cultured under normal conditions

Statistical analyses were performed using dispersion analysis. A P value of $<0.05$ was considered statistically significant.

\section{Results}

Fig. 1-4 depict the culture results of cancer cells in the presence of nitrous oxide at different pressure values, exposure times and concentrations of MTX. In CCRF-CEM suspension cells, the $\mathrm{S} / \mathrm{N}$ ratio was the lowest (60.6\%) when they were cultured at $2 \mathrm{~atm}$ for 24 hours with $10 \mu \mathrm{M}$ MTX (Fig. 1). The difference in the $\mathrm{S} / \mathrm{N}$ ratio was statistically significant between cells at 1 and 2 atm than those at 2 and 3 atm ( $P$ $<0.05)$, but there was no significant correlation between pressure and the mean $\mathrm{S} / \mathrm{N}$ ratio. The $\mathrm{S} / \mathrm{N}$ ratio was $87.4 \%$ at an exposure time of 24 hours, $95.0 \%$ at an exposure of 48 hours and $115.9 \%$ at an exposure time of 72 hours, which implied that the mean $\mathrm{S} / \mathrm{N}$ ratio became higer with increasing exposure time. The mean S/N ratio was the lowest (78.6\%) without the administration of MTX, and it increased with the
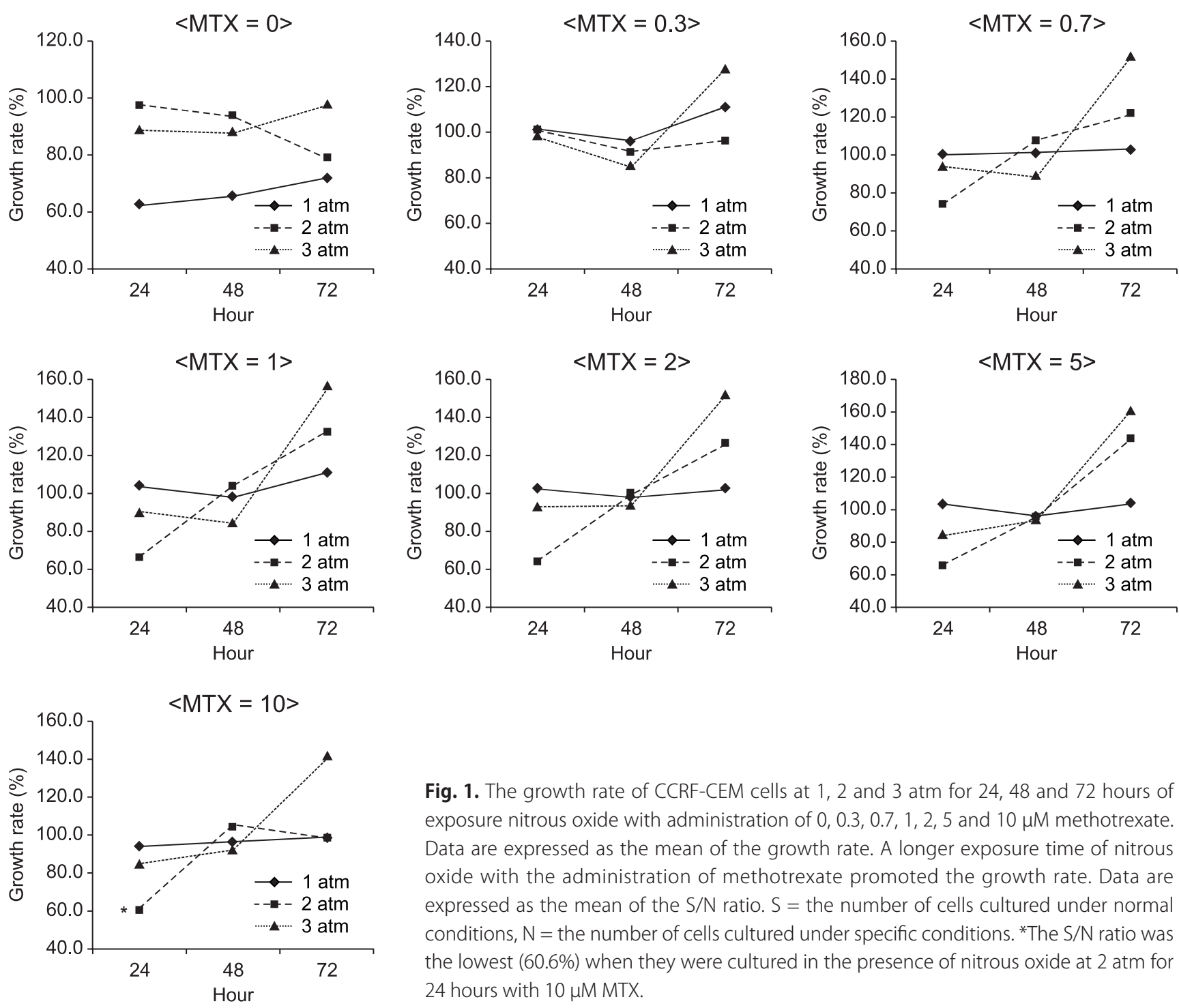

Fig. 1. The growth rate of CCRF-CEM cells at 1,2 and 3 atm for 24,48 and 72 hours of exposure nitrous oxide with administration of $0,0.3,0.7,1,2,5$ and $10 \mu \mathrm{M}$ methotrexate. Data are expressed as the mean of the growth rate. A longer exposure time of nitrous oxide with the administration of methotrexate promoted the growth rate. Data are expressed as the mean of the $\mathrm{S} / \mathrm{N}$ ratio. $\mathrm{S}=$ the number of cells cultured under normal conditions, $\mathrm{N}=$ the number of cells cultured under specific conditions. ${ }^{*}$ The $\mathrm{S} / \mathrm{N}$ ratio was the lowest (60.6\%) when they were cultured in the presence of nitrous oxide at $2 \mathrm{~atm}$ for 24 hours with $10 \mu \mathrm{M}$ MTX. 

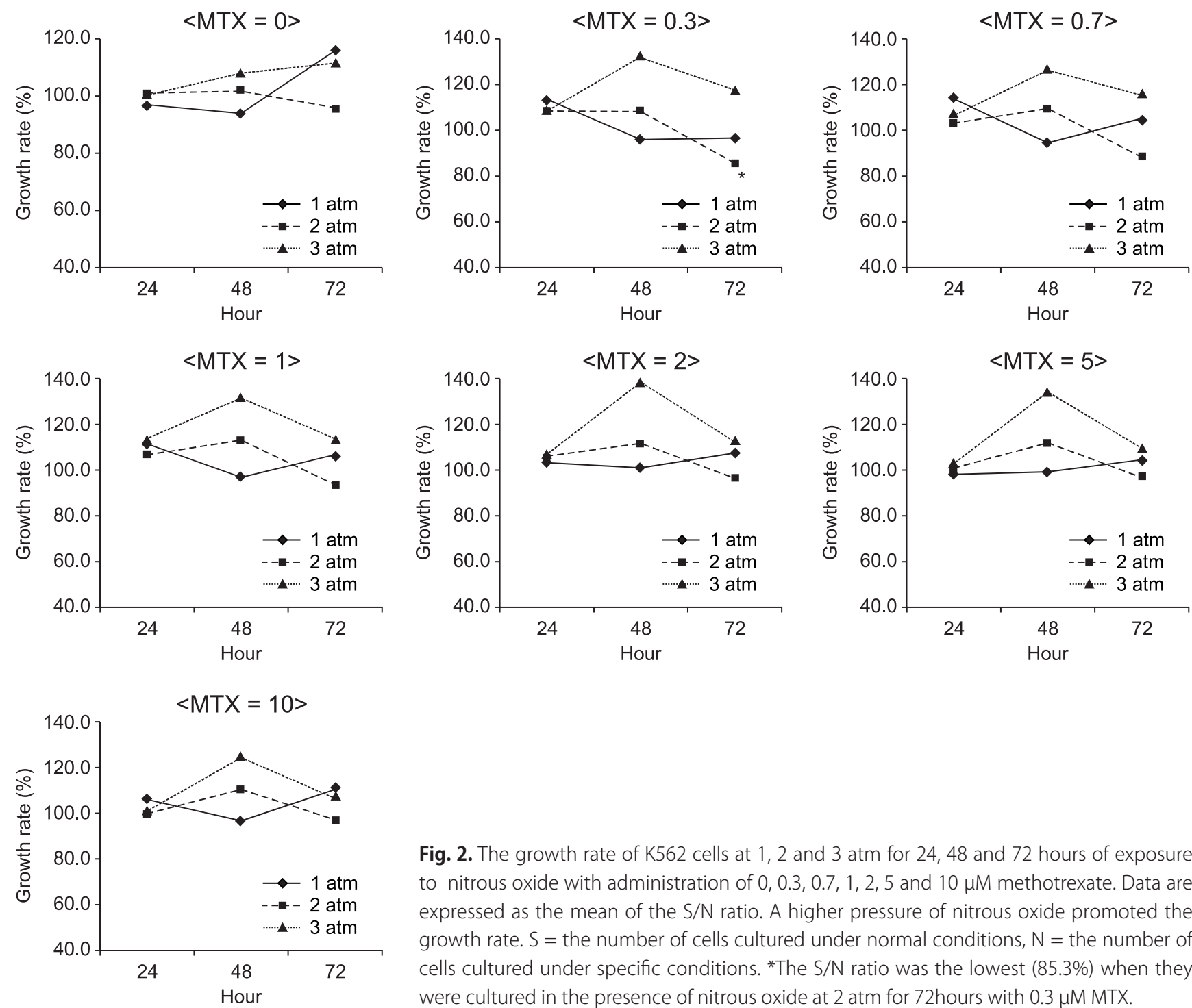

Fig. 2. The growth rate of $\mathrm{K} 562$ cells at 1,2 and 3 atm for 24, 48 and 72 hours of exposure to nitrous oxide with administration of $0,0.3,0.7,1,2,5$ and $10 \mu \mathrm{M}$ methotrexate. Data are expressed as the mean of the $\mathrm{S} / \mathrm{N}$ ratio. A higher pressure of nitrous oxide promoted the growth rate. $S$ = the number of cells cultured under normal conditions, $N=$ the number of cells cultured under specific conditions. ${ }^{*}$ The $\mathrm{S} / \mathrm{N}$ ratio was the lowest (85.3\%) when they were cultured in the presence of nitrous oxide at 2 atm for 72 hours with $0.3 \mu \mathrm{M}$ MTX.

administration of MTX $(P<0.05)$.

In K562 suspension cells, the S/N ratio was the lowest (85.3\%) when they were cultured in the presence of nitrous oxide at $2 \mathrm{~atm}$ for 72 hours with $0.3 \mu \mathrm{M}$ MTX (Fig. 2). The mean S/N ratio was $103.6 \%$ at $1 \mathrm{~atm}, 102.4 \%$ at $2 \mathrm{~atm}$ and $115.6 \%$ at 3 atm, which implied that the $\mathrm{S} / \mathrm{N}$ ratio became higher as the pressure increased $(P<0.05)$. The $\mathrm{S} / \mathrm{N}$ ratio was $105 \%$ at an exposure time of 24 hours, $111.9 \%$ at an exposure time of 48 hours and $104.2 \%$ at an exposure time of 72 hours, but the differences were not statistically significant. There was no significant difference in the $\mathrm{S} / \mathrm{N}$ ratio between the different concentrations of MTX, either $(P>0.05)$.

In A549 adhesion cells, the S/N ratio was the lowest (74.5\%) when they were cultured in the presence of nitrous oxide at 2 atm for 24 hours (Fig. 3). The S/N ratio was $94.3 \%$ at 1 atm, $94.1 \%$ at $2 \mathrm{~atm}$ and $99.3 \%$ at $3 \mathrm{~atm}$, but the differences were not statistically significant. The $\mathrm{S} / \mathrm{N}$ ratio was $96.2 \%$ at an exposure time of 24 hours, $99.2 \%$ at an exposure time of 48 hours and $92.3 \%$ at an exposure time of 72 hours, but the differences were not statistically significant. There was no significant difference in the $\mathrm{S} / \mathrm{N}$ ratio between different concentrations of MTX, either $(P>0.05)$.

In MDA-MB-231 adhesion cells, the S/N ratio was the lowest (50.6\%) when they were cultured in the presence of nitrous oxide at $1 \mathrm{~atm}$ for 48 hours with the administration of $0.3 \mu \mathrm{M}$ MTX (Fig. 4). The mean S/N ratio was $66.9 \%$ at $1 \mathrm{~atm}, 83.1 \%$ at $2 \mathrm{~atm}$ and $87.8 \%$ at $3 \mathrm{~atm}$, which implied that the mean S/N ratio significantly became higher as pressure increased. The mean S/N ratio was $88.7 \%$ at an exposure of 24 hours, $78.1 \%$ at an exposure of 48 hours and $71.1 \%$ at an exposure time of 72 hours, which implied that the mean $\mathrm{S} / \mathrm{N}$ ratio significantly became lower as the exposure time increased. However, there was no significant difference in the $\mathrm{S} / \mathrm{N}$ ratio between the different concentrations of MTX.

Table 2 shows the inhibitory effects of nitrous oxide on the 4 kinds of cancer cells according to pressure and exposure time. 

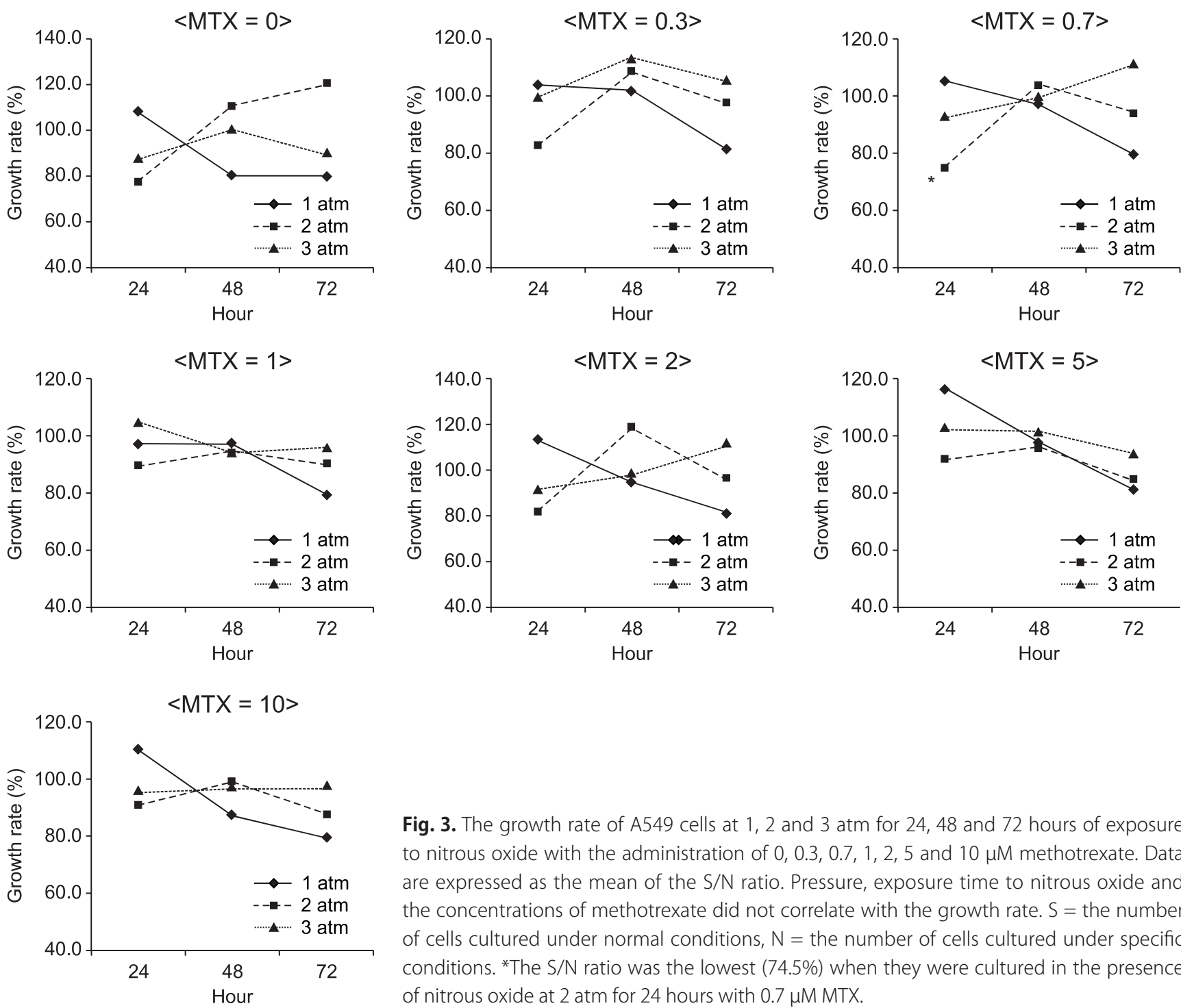

Fig. 3. The growth rate of $A 549$ cells at 1,2 and 3 atm for 24,48 and 72 hours of exposure to nitrous oxide with the administration of $0,0.3,0.7,1,2,5$ and $10 \mu \mathrm{M}$ methotrexate. Data are expressed as the mean of the $\mathrm{S} / \mathrm{N}$ ratio. Pressure, exposure time to nitrous oxide and the concentrations of methotrexate did not correlate with the growth rate. $S=$ the number of cells cultured under normal conditions, $\mathrm{N}=$ the number of cells cultured under specific conditions. ${ }^{*}$ The $\mathrm{S} / \mathrm{N}$ ratio was the lowest $(74.5 \%)$ when they were cultured in the presence of nitrous oxide at $2 \mathrm{~atm}$ for 24 hours with $0.7 \mu \mathrm{M}$ MTX.

The S/N ratio of MDA-MB-231 cells decreased only at a long exposure time. In CCRF-CEM cells, a long time exposure to nitrous oxide with the administration of MTX increased the $\mathrm{S} /$ $\mathrm{N}$ ratio, whereas in $\mathrm{K} 562$ and MDA-MB-231 cells, the pressure of nitrous oxide increased the $\mathrm{S} / \mathrm{N}$ ratio. In contrast, without the administration of MTX, the S/N ratio decreased only in MDA-MB-231 cells when the cancer cells were exposed to nitrous oxide for a longer time, whereas it increased when the cancer cells were exposed to nitrous oxide at higher pressures. Overall, the $\mathrm{S} / \mathrm{N}$ ratio was the lowest (50.6\%) when the cancer cells were exposed to nitrous oxide at $1 \mathrm{~atm}$ for 48 hours with the administration of 0.3 um MTX. The S/N ratio ranged between $100.2 \%$ and $115.6 \%$ in K562 cells and between $92.3 \%$ and $100.1 \%$ in A549 cells, both of which exceeded an S/N ratio of $100 \%$. This result indicated that a combined administration of hyperbaric nitrous oxide and MTX had no significant inhibitory effect on the growth of cancer cells (Fig. 2 and 3). However, the inhibitory effect of nitrous oxide on the $\mathrm{S} / \mathrm{N}$ ratio was greatest in MDA-MB-231 cells out of the 4 aforementioned cancer cells, especially at 2 or 3 atm at an exposure time of 72 hours without the administration of MTX (Fig. 4)

\section{Discussion}

Numerous studies have been attempted on the neurotoxicity of nitrous oxide [11,12] and a measure for anticancer therapy [10,13-15] on the basis of the fact that nitrous oxide impairs the synthesis of DNA. It was reported that nitrous oxide inhibited $50 \%$ of cell growth in leukemic cells at 1 atm, and such effects was greater in combination with 5-fluorouracil, a dihydrofolate reductase inhibitor [16]. Previous studies on the antileukemic effect of nitrous oxide have been conducted only at 1 atm or at different fractions 

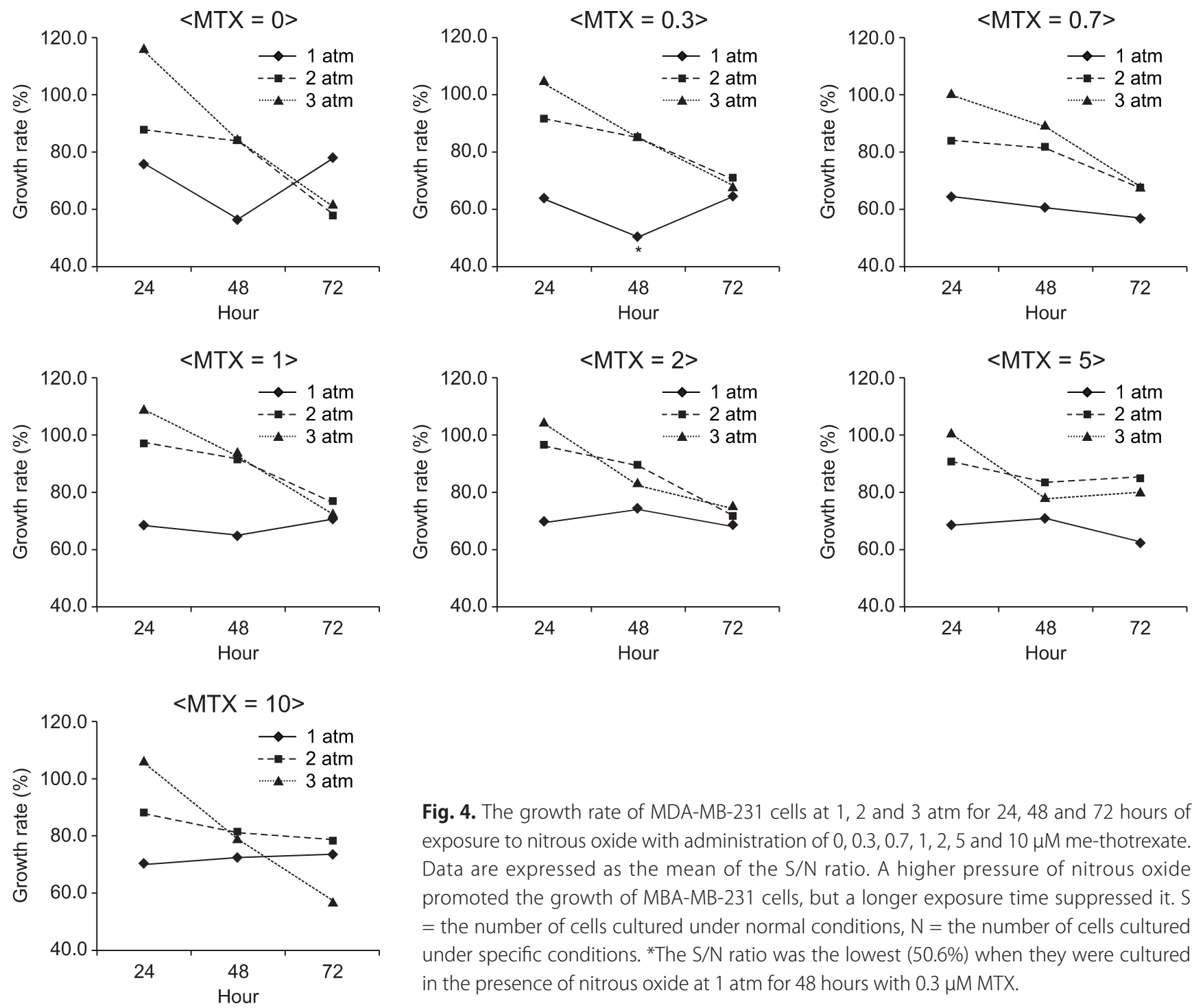

Fig. 4. The growth rate of MDA-MB-231 cells at 1,2 and 3 atm for 24, 48 and 72 hours of exposure to nitrous oxide with administration of $0,0.3,0.7,1,2,5$ and $10 \mu \mathrm{M}$ me-thotrexate. Data are expressed as the mean of the $\mathrm{S} / \mathrm{N}$ ratio. A higher pressure of nitrous oxide promoted the growth of MBA-MB-231 cells, but a longer exposure time suppressed it. S $=$ the number of cells cultured under normal conditions, $\mathrm{N}=$ the number of cells cultured under specific conditions. ${ }^{*}$ The S/N ratio was the lowest (50.6\%) when they were cultured in the presence of nitrous oxide at $1 \mathrm{~atm}$ for 48 hours with $0.3 \mu \mathrm{M}$ MTX.

Table 2. The Averaged Overall Growth Suppression of Each Cancer Cell Line Based on the Suppression Conditions

\begin{tabular}{|c|c|c|c|c|}
\hline & CCRF-CEM & K562 & A549 & MDA-MB-231 \\
\hline $\mathrm{N} 2 \mathrm{O}$ pressure & Variable* & Growth increased $^{+}$ & Variable & Growth increased \\
\hline Exposure duration & Growth increased & Variable & Variable & Growth suppressed \\
\hline Methotrexate & Growth increased & Variable & Variable & Variable \\
\hline
\end{tabular}

${ }^{*}$ No fixed pattern of relative cell growth under this condition. ${ }^{\dagger}$ The relative cell growth rate is higher under this condition than under normal conditions. The absolute number of incubated cells decreased.

or exposure times. For instance, the antileukemic effect was investigated after nitrous oxide was administered at a fraction of 50\% (260 mmHg) or $80 \%$ (608 $\mathrm{mmHg}$ ) for a longer period of time (18 or 24 hours) which did not reach 1 MAC (798 $\mathrm{mmHg}$ [ [17]. In other words, this experiment was conducted when $25 \%-30 \% \mathrm{O}_{2}(190-228 \mathrm{mmHg})$ was provided with the maximal fraction of nitrous oxide. In addition, the growth suppression of leukemic cells by hyperbaric nitrous oxide has been studied [10]. In this study, the S/N ratio was assessed at different exposure times to hyperbaric nitrous oxide and different concentrations of MTX. As a result, the growth of MDA-MB-231 cells tended to be suppressed when they were exposed to nitrous oxide for a longer period of time. However, they were not remarkably suppressed in the other conditions or even accelerated in certain conditions. Although both nitrous oxide and MTX impair DNA synthesis, cell growth was suppressed only in MDA-MB-231 cells in our study.

Plausible reasons for this result may be explained as follows. 


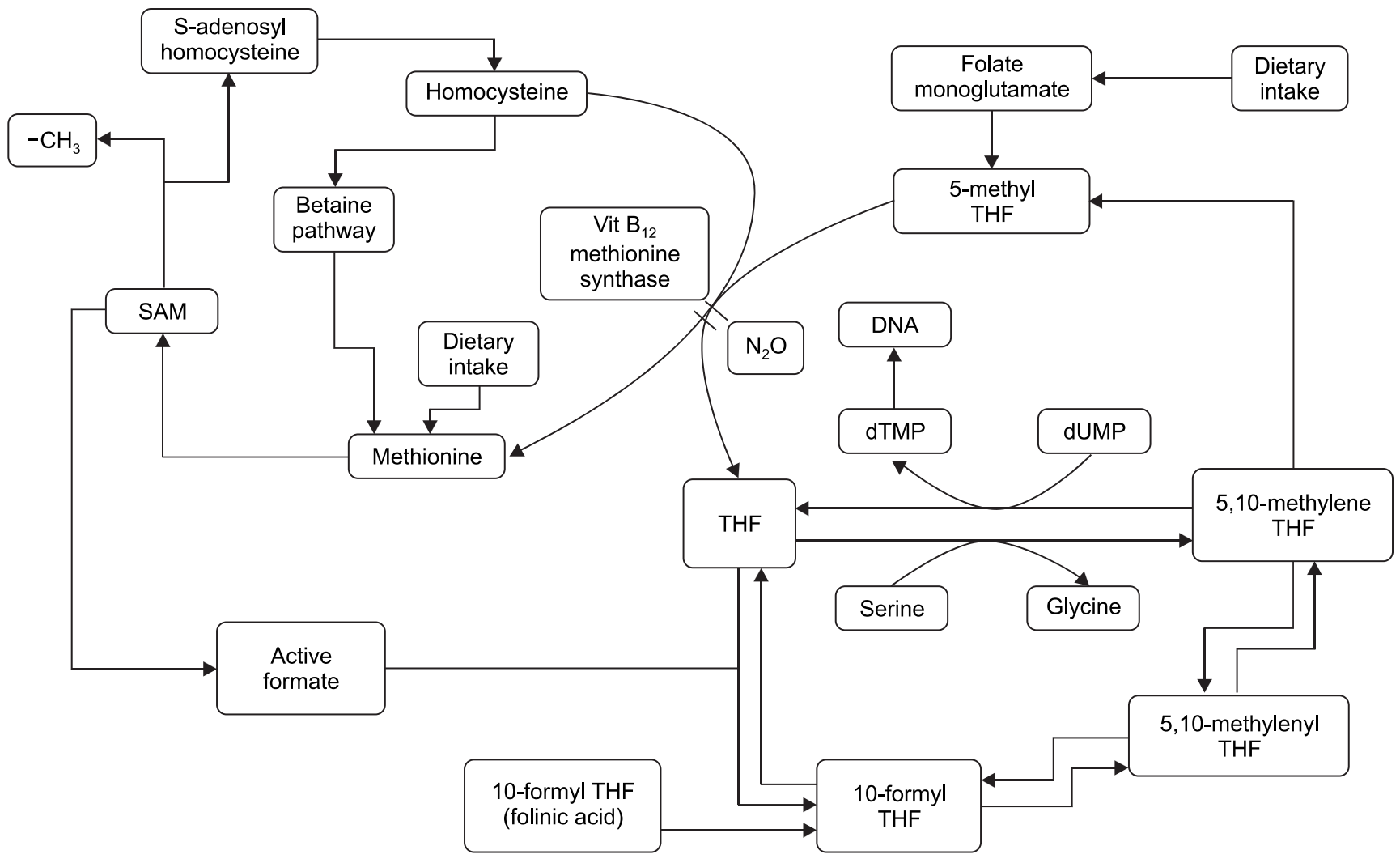

Fig. 5. The dTMP synthase process for DNA synthesis and the role of methionine synthase. When nirous oxide inactivates methionine synthase which is composed of vitamine B12, tetrahydrofolate formation is decreased. Consequently, dTMP and DNA are inactivated.

Several antitumor agents including MTX suppress cell growth by impairing DNA synthesis through the inactivation of folate metabolism. Like other antitumor agents, inactivated folate metabolism inhibits the growth of cancer cells as well as normal cells, subsequently leading to serious side effects. For this reason, numerous studies have been conducted not only to develop methods to maximally suppress the growth of cancer cells but also to simultaneously achieve the minimal deleterious effect on normal cells. Moreover, there have been several studies on the restriction of diet containing amino acids related to folate metabolism or the suppression of growth of cancer cells by administration of nitrous oxide [1, $18,19]$. The administration of nitrous oxide is based on the fact that nitrous oxide impairs DNA synthesis and suppress cell growth by inactivation of methionine synthase through the irreversible oxidation of cobalt atoms in vitamin $B_{12}[8,9$, 20] (Fig. 5). MTX and nitrous oxide suppress cell growth in a similar manner. However, in our study, when these similarly acting drugs were simultaneously administered, synergistic actions were not observed. This result may be explained as follows. Considering the combined effects of nitrous oxide and MTX, MTX concentration did not have significant effect on cell growth, and only the presence of MTX did. All kinds of cells showed similar suppression of cell growth at $\geq 0.3 \mu \mathrm{M}$ MTX.
Furthermore, the pressure of and exposure time to nitrous oxide are not related to cell growth, and only the administration of MTX sufficiently inactivates vitamin $B_{12-}$ dependent methionine synthase. Further experiments should be performed at concentrations that show synergistic actions with nitrous oxide before the time point where the suppression effect becomes maximal using $>0.3 \mu \mathrm{M}$ MTX.

Meanwhile, the definition of cell growth suppression differs among studies. In this study, the suppression of cell growth was defined as the ratio of growth of cells cultured under specific conditions to that of cells cultured under normal conditions. Few studies have been conducted to determine whether changes in pressure could influence cell growth in hyperbaric nitrous oxide with MTX. Although we expected that cell growth would be suppressed through the synergistic action by combined administration of MTX and hyperbaric nitrous oxide, cell growth remained unchanged or even accelerated. A plausible reason for this is as follows. Although MTX considerably influenced the growth of cells cultured under normal conditions, it exerted relatively little effect on cells cultured in hyperbaric nitrous oxide for a longer period of time. As a result, the $\mathrm{S} / \mathrm{N}$ ratio decreased. Considering that the absolute number of cells measured under specific conditions with hyperbaric nitrous oxide decreased com- 
pared to that measured under normal conditions, it may be difficult to determine the suppression or acceleration using the $\mathrm{S} / \mathrm{N}$ ratio. However, we used this ratio because there was no appropriate countermeasure. A previous study similar to ours has proposed that when cancer cells (CCRF-CEM) together with lymphocytes from normal blood were placed under specific conditions with hyperbaric nitrous oxide, cell growth is significantly suppressed by nitrous oxide at $1 \mathrm{~atm}$ for 48 hours. It was different from ours in that it compared cell growth between cancer and normal cells. In other words, our study compared cell growth between cancer cells obtained from the same cell line. In addition, hyperbaric condition should not be overlooked with respect to cell growth. Based on the prerequisite that pressure itself does not influence cell growth, we hypothesized that a large amount of nitrous oxide could suppress cell growth. However, in this study, seeing that hyperbaric nitrous oxide did not considerably influence cell growth, a pressure of 2 or $3 \mathrm{~atm}$ seemed to influence cell growth to some extent. It was found that hyperbaric nitrous oxide did not considerably influence cell growth. This result can be explained by the assumption that nitrous oxide itself suppresses cell growth, while hyperbaric condition accelerates cell growth. This assumption is based on the finding that cell growth was suppressed more at $1 \mathrm{~atm}$ than 2 or 3 atm in the absence of MTX (Fig. 1-4).

In this study, despite an increase in pressure, cell growth in a hyperbaric condition was not significantly different from that under normal conditions. A possible reason for this result may be due to the supply of a large amount of oxygen. Partial pressure of oxygen was $160 \mathrm{mmHg}$ at $1 \mathrm{~atm}, 320 \mathrm{mmHg}$ at $2 \mathrm{~atm}$ and $480 \mathrm{mmHg}$ at $3 \mathrm{~atm}$. When a large number of oxygen is supplied, oxygen radical may be induced and thus suppresses cell growth. Meanwhile, cell growth can be accelerated due to a sufficient amount of oxygen, which may explain our result that there was no significant suppression of cell growth despite the administration of hyperbaric nitrous oxide. Future work will focus on the investigation of the effect of only an increase in pressure at a constant $\mathrm{O}_{2}$ partial pressure on cell growth by performing experiments using 5\% $\mathrm{CO}_{2}-21 \% \mathrm{O}_{2}-74 \% \mathrm{~N}_{2} \mathrm{O}$ at $1 \mathrm{~atm}$ as well as $100 \% \mathrm{~N}_{2} \mathrm{O}$ at a $\mathrm{O}_{2}$ partial pressure of $160 \mathrm{mmHg}$ in order to confirm our result.

Taken together, in our experiments using 4 kinds of cancer cell lines (CCRF-CEM, K562, A549 and MDA-MB-231) by the administration of hyperbaric nitrous oxide for a longer period of time as well as MTX which inactivated methionine synthase in the same manner, the MDA-MB-231 cell line tended to suppress cell growth only when hyperbaric nitrous oxide was administered for a longer time. This result can be explained by a relatively excessive administration of MTX, establishment of the comparison group for the evaluation of the cell growth rate, the effect of pressure itself on cell growth and the administration of a high concentration of oxygen. The results of this study suggest that the administration of nitrous oxide for a longer period of time may suppress growth of the cancer cell lines, especially the MDA-MB-231 cell line.

\section{Acknowledgements}

This study was supported by grant no 11-2003-0007 from the SNUH Research Fund.

\section{References}

1. Koblin DD. Nitrous oxide: a cause of cancer or chemotherapeutic adjuvant? Semin Surg Oncol 1990; 6: 141-7.

2. Myles PS, Leslie K, Silbert B, Paech MJ, Peyton P. A review of the risks and benefits of nitrous oxide in current anaesthetic practice. Anaesth Intensive Care 2004; 32: 16572.

3. Baum JA. The carrier gas in anaesthesia: nitrous oxide/ oxygen, medical air/oxygen and pure oxygen. Curr Opin Anaesthesiol 2004; 17: 513-6.

4. Russell GB, Snider MT, Richard RB, Loomis JL. Hyperbaric nitrous oxide as a sole anesthetic agent in humans. Anesth Analg 1990; 70: 289-95.

5. Baum VC. When nitrous oxide is no laughing matter: nitrous oxide and pediatric anesthesia. Paediatr Anaesth 2007; 17: 824-30.

6. Weimann J. Toxicity of nitrous oxide. Best Pract Res Clin Anaesthesiol 2003; 17: 47-61.

7. Doran M, Rassam SS, Jones LM, Underhill S. Toxicity after intermittent inhalation of nitrous oxide for analgesia. BMJ 2004; 328: 1364-5.

8. Kroes AC, Lindemans J, Hagenbeek A, Abels J. Nitrous oxide reduces growth of experimental rat leukemia. Leuk Res 1984; 8: 441-8.

9. Reynolds E. Vitamin B12, folic acid, and the nervous system. Lancet Neurol 2006; 5: 949-60.

10. Ahn WS, Kim JY, Bahk JH, Park CD, Kim SD. Growth Suppression of Leukemic Cells by Hyperbaric Nitrous Oxide and Methotrexate. Korean J Anesthesiol 2006; 50: 308-14.

11. Sanders RD, Weimann J, Maze M. Biologic effects of nitrous oxide: a mechanistic and toxicologic review. Anesthesiology 2008; 109: 707-22.

12. Taninishi H, Takeda Y, Kobayashi M, Sasaki T, Arai M, Morita K. Effect of nitrous oxide on neuronal damage and extracellular glutamate concentration as a function of mild, moderate, or severe ischemia in halothane-anesthetized gerbils. Anesthesiology 2008; 108: 1063-70.

13. Forest V, Peoc'h M, Campos L, Guyotat D, Vergnon JM. Benefit of a combined treatment of cryotherapy and chemotherapy on tumour growth and late cryo-induced angiogenesis in a non-small-cell lung cancer model. Lung 
Cancer 2006; 54: 79-86.

14. Mariategui J, Santos C, Taxa L, Jeronimo J, Castle PE. Comparison of depth of necrosis achieved by $\mathrm{CO} 2-$ and N2O-cryotherapy. Int J Gynaecol Obstet 2008; 100: 24-6.

15. Forest V, Hadjeres R, Bertrand R, Jean-Francois R. Optimisation and molecular signalling of apoptosis in sequential cryotherapy and chemotherapy combination in human A549 lung cancer xenografts in SCID mice. Br J Cancer 2009; 100: 1896-902.

16. Ermens AA, Schoester M, Lindemans J, Abels J. Effect of nitrous oxide and methotrexate on folate coenzyme pools of blast cells from leukemia patients. Leuk Res 1991; 15: 165-71.

17. Fiskerstrand T, Ueland PM, Refsum H. Folate depletion induced by methotrexate affects methionine synthase activity and its susceptibility to inactivation by nitrous oxide. J Pharmacol Exp Ther 1997; 282: 1305-11.

18. Kroes AC, Lindemans J, Schoester M, Abels J. Enhanced therapeutic effect of methotrexate in experimental rat leukemia after inactivation of cobalamin (vitamin B12) by nitrous oxide. Cancer Chemother Pharmacol 1986; 17: $114-20$.

19. Lumb M, Perry J, Deacon R, Chanarin I. Changes in plasma folate levels in rats inhaling nitrous oxide. Scand J Haematol 1981; 26:61-4.

20. Kondo H, Osborne ML, Kolhouse JF, Binder MJ, Podell ER, Utley CS. Nitrous oxide has multiple deleterious effects on cobalamin metabolism and causes decreases in activities of both mammalian cobalamin-dependent enzymes in rats. J Clin Invest 1981; 67: 1270-83. 